\title{
Creating operational alpha? Operating models for real estate management
}

Article

Accepted Version

McAllister, P. (2020) Creating operational alpha? Operating models for real estate management. Property Management, 38 (4). pp. 565-583. ISSN 0263-7472 doi:

https://doi.org/10.1108/PM-02-2020-0009 Available at https://centaur.reading.ac.uk/91391/

It is advisable to refer to the publisher's version if you intend to cite from the work. See Guidance on citing.

To link to this article DOI: http://dx.doi.org/10.1108/PM-02-2020-0009

Publisher: Emerald

All outputs in CentAUR are protected by Intellectual Property Rights law, including copyright law. Copyright and IPR is retained by the creators or other copyright holders. Terms and conditions for use of this material are defined in the End User Agreement.

\section{www.reading.ac.uk/centaur}

\section{CentAUR}

Central Archive at the University of Reading

Reading's research outputs online 
Creating Operational Alpha? Operating Models for Real Estate Management

\author{
Pat McAllister
}

(Property Management, forthcoming) 


\begin{abstract}
Purpose: Focussing on the UK's institutional real estate universe, this paper analyses variations in the operational management of real estate investment portfolios. For the main categories of institutional investors, the key tasks in real estate operational management and the ways in which these tasks are typically bundled and categorised by investment managers are reviewed. Three broad operational management models are outlined. Case studies of real estate operational management models in practice are discussed.
\end{abstract}

Approach: The research approach is primarily descriptive drawing upon illustrative investor case studies.

Findings: A range of operating models are identified for managing real estate investment portfolios. Specialists real estate investors tend to have highly vertically integrated operating models viewing most operational management functions as core operational capabilities. Multi-asset owners tend to have a vertically disintegrated operating model outsourcing fund, asset, property and facilities management. Investing institutions such as fund houses and specialist real estate investment advisors seem to have converged upon a common hybrid operating model with high margin, analytical functions such as fund and asset management being insourced and low margin, routine functions such as property and facilities management being outsourced.

Originality/value: Despite the size of the global, institutional real estate investment universe (estimated by DTZ to be worth more than USD 13.6 trillion in 2015), the topic of how (and how effectively) these assets are managed by institutional investors has attracted very little attention from the real estate research community. This paper provides some initial analysis and insights into operational management models for real estate investment portfolios in the contemporary real estate investment management landscape. 


\section{Introduction}

As a real asset class, a key characteristic of direct investment in real estate assets is that it requires a relatively substantial (if variable) operational management input by investors, external suppliers and/or occupiers. It can be easy to underestimate the range of tasks that need to be performed or procured by owners and occupiers in order to operate the diverse and often complex bundles of technology, materials, services, financial flows, legal obligations, regulatory responsibilities, contractual and business relationships and associated risks embedded in commercial real estate assets. For investors and occupiers, real estate operational management can be a cost, a profit centre, a potential core capability, and a source of competitive advantage and added value. For investors specifically, improvements to operational efficiency and effectiveness can enhance investment performance. For each investing organisation, an important decision is how to identify and deliver the optimal operating model for real estate management functions such as fund, asset, property and facilities management.

In a dynamic real estate investment sector, there is limited up-to-date description and analysis of the investor and operational landscape. From an institutional economics perspective, the market outcome in terms of real estate operational management models can be framed as path dependent and contingent upon a combination of historic chance and deliberate agency. Feedback effects can 'lock in' a particular market outcome that has (by chance) emerged from multiple potential equilibrium states. In the UK, the long-term presence of large institutional investors (mainly occupational pension funds and insurance companies) has generated the initial conditions for the growth of third party fund, asset and property management services. In turn, the presence of these third party providers expedited the vertical disintegration of many real estate operational management services.

Until the 1990s, the most common operational management model involved the majority of operational management functions being internally delivered by a single investment organisation. However, over the last two decades, in many markets there seems to have been a secular shift towards outsourcing many operational management functions adopting a market approach to the governance of these functions. Paradoxically, at the same time some major real estate investment organisations have persisted with a hierarchical governance approach regarding most real estate operational management functions as core competencies meriting an in-house capability. Using the UK market as a case study, this paper explores these differences in real estate operational management models.

As noted above, although there will be 'legacy' issues, when operating real estate assets, owners and investment managers need to decide upon an operational management strategy. They can choose to outsource or insource the different operational management functions or to adopt different solutions for 
different markets, sectors or functions. If delivering an operational management task themselves, it is implicitly expected that the trade-off between service quality and cost will be superior to a third party solution. As well as depending on the presence, competency and cost of third party providers, the optimal operational solution will also hinge on the competency, capacity and costs of investor or investment managers to deliver the service. Some investors may conclude that they have little competitive advantage in any operational management functions for any real estate assets in any markets. Others may conclude that they have competitive advantage compared to third party providers in some markets and sectors particularly where they are regarded as core and/or critical to their business model. Close control of the operational management of key assets may be critical to some investors or investment managers. They may also conclude that certain key operational management tasks or functions are delivered best internally whilst it is optimal to adopt third party solutions for others. The range of potential operational models is large with each real estate investor able to create their own bespoke model.

The focus of this paper is on the operational management of direct equity investments in real estate assets (as opposed to indirect investments or real estate debt markets). Although there is some description of market practices, the paper is not primarily empirical. It is not based upon systematic research involving quantitative or qualitative surveys of practice. A small number of interviews (3) were carried out in order to fill in gaps in areas where the author was unsure of current practice in terms of operating model. Some limited content analysis of annual reports, websites etc. was performed to confirm or identify practice and Falkenbach et al's (2017) paper was also helpful in gathering evidence of current (2016-7) practices. The reminder of the paper is organised as follows. The first section provides an overview of the key tasks in the operational management of commercial real estate portfolios and the ways in which these tasks are typically bundled and categorised by investment managers and third party service providers. This section is followed by an analysis of the main categories of institutional investors in commercial real estate in terms of their geographical, sector and asset foci and their operating and business models. Mainly focussing on asset and property management, the third section outlines three broad operational management models used by real estate investors and investment managers. With a specific focus on the UK market and the decision whether to insource or outsource property management, the fourth section discusses the UK real estate market. This is followed by an analysis of the property management sector in the UK. Examples of real estate operational management models in practice in the UK are then discussed. Finally, conclusions are drawn.

\section{Real Estate Operational Management: A Task Audit}


Operational (or operations) management is typically concerned with the design, management and improvement of operational systems. Largely focused on process and strategy, it tends to be concerned with the effective deployment of resources to produce services and products. In the context of direct real estate investment, it relates to how the delivery of the wide range of operational tasks or functions associated with fund, asset, property and facilities management as well as specialist real estate functions and ancillary support services is structured, procured and delivered. Even within the broad operational models outlined later in this paper, there can be numerous permutations in terms of how real estate investment organisations structure the internal and/or external delivery different (bundles of) operational tasks and functions.

Although real estate operational management tasks will be broadly similar in most markets, before considering the operational management models in more detail it is worth briefly re-iterating the broad range of tasks that need to be performed when operating real estate investment assets. Whilst there is invariably a significant degree of consultation, collaboration and even co-production between different roles and organisations, the typical allocation of operational tasks is set out in Table 1.

\section{Insert Table 1 around here}

Geltner (2003) presented a model of the four fundamental property level investment management functions of; property selection, acquisition transaction execution, operational management and and disposition transaction execution. Below, Geltner's basic model is extended to illustrate where and how these four core investment management activities may affect investment performance. The models are based largely on deductive reasoning. Some of the premises of the models would be regarded as selfevident e.g. stock selection asset allocation are important determinants of investment performance. Others would be less self-evident e.g. operational model influences investment performance, higher tenant satisfaction leads to lower voids etc. and are far from empirically proven.

Focussing first on property and facilities management, as illustrated in Figure 1 there is likely to be a degree of conflict between cost and quality in the transmission mechanism from property and facilities management to investment performance. Similar to many business operations, optimising the costservice level trade-off is a key calibration. Albeit a large proportion of the costs may be recoverable through service charges (see below), property and facilities management is a direct cost to real estate investors. Consequently, the relative productivity of property and facilities management service providers will produce variations in this cost which will directly affect the level of net income received. All else equal, the less efficient the provider, the higher will be the direct cost to the investor and occupier. More indirectly, lower operating expenses will tend to have positive effects on demand for the asset from existing and potential occupiers. The expected transmission mechanism here is tenant 
satisfaction. Where occupiers are satisfied with the cost and quality of property and facilities management, it seems reasonable to assume that they are more likely to pay rent and service charges on time and to remain in the property. In addition and in conjunction with facilities and asset managers, property managers are also in a position to identify potential opportunities to add value to assets and enhance income and capital returns (or reduce risks) by executing unplanned interventions to improve the tenant, lease structures, building, use, legal title etc.

However, the main responsibility for identifying and executing value add opportunities at the asset level lies mainly with the asset manager. As set out in Figures 2, their core responsibilities can be to instruct, coordinate with and (sometimes) monitor property and facilities managers, execute acquisitions and disposals and to add value to the assets. It is also worth noting that there has been a growing trend to shift the responsibility for monitoring the performance of property managers from asset managers to specialists. Where property management is outsourced, these roles typically involve the procurement and performance monitoring of property management services. Often the role is described as Director or Head of Operations. When internally delivered, the property management team may be structured to provide career progression in specialist property management roles.

For asset managers, 'adding value' tends to involve discretionary managerial interventions by the real estate asset manager with the aim of improving assets' risk-adjusted performance. Often labelled active asset management, it encompasses modifying assets' legal, physical, use, financial and occupational structures and attributes in order to increase value. Generally requiring an entrepreneurial outlook, common interventions include upgrading and reconfiguring buildings and their services, extending the building, improving tenant quality, improving lease structures, shifting to highest and best use, removing onerous legal restrictions on legal titles etc. In shopping centres, commercialisation or speciality leasing strategies have generated a growing range of sector-specific opportunities for 'alternative' revenue generation.

Supervised by Investment Committees, clients and fund managers and advised by a range of specialists, asset managers are often responsible for sourcing and executing the acquisition and disposal of individual assets. However, even for this single operational function, there is a debate about the best operational approach. McAllister, Hughes and Gallimore (2006) found a clear dichotomy between organisations in their use of either in-house transaction specialists or asset managers to execute transactions. Organisations who had transaction specialists tended to emphasise the importance of quick responses, focus on sourcing stock and market contact and knowledge. Organisations who combine the roles of asset management and transaction execution stressed the risk control aspects of buyers managing the assets that they purchase. However, they also identified a trade-off in that the quality of 
asset management could be adversely affected by the diversion of resources devoted to acquiring or disposing of stock.

Fund managers generally influence the operational management of real estate assets through their strategic decision-making. The transmission of their core responsibilities to portfolio returns and risks are illustrated in Figure 3. Their asset allocation strategies for sector and geographical capital deployment and decisions on stock acquisition and disposal along with capital structuring will almost certainly generate their most significant impact on real estate portfolio's risk-adjustment performance. However, whilst the operating model is a strategic investment management decision, very little is actually known about the relative importance and impact of operating model on investment performance.

\section{Insert Figures 1-3 around here}

\section{The Investing Institutions}

An evaluation of the various operational solutions for real estate investment strategies is complicated by the sheer diversity and complexity of the real estate investment (management) sector. Broadly, many categories of investor will be both consumers and producers of third party fund and asset management services. The lines between advisors, managers and investors have become increasingly blurred. Baum and Hartzell $(2012,9)$ referred to the creation of "a more complex industry structure and a confusion of ownership and management". The 'pure' investors (who outsource to third party investment managers) tend to be trusts, small and medium sized pension funds, foundations, endowments, sovereign wealth funds and high net worth individuals. Whilst a small proportion of the former will offer third party fund and asset management services, the investment management sector generally comprises large pension funds, insurers, fund houses, specialist real estate investment managers, investment banks and private equity funds who essentially act as aggregators of institutional capital. Often cooperating and competing using a myriad of separate accounts, non-discretionary mandates, pooled funds, joint ventures and investment platforms, some of these investing organisations are both simultaneously clients and providers of third party real estate asset management services. The major full service investment banks offer their own suite of real estate investment products and investment management services which are often relatively minor elements of their wider business.

Hybrid business models are common with investing organisations such as Hines, Brookfield and Tishman Speyer specialising in investing in, operating and developing real estate assets across many national markets. They offer third party real estate fund, asset and property management services, a range of pooled investment funds and platforms, engage in joint ventures and partnerships and operate 
through subsidiaries etc. They may be investing their own capital and/or offering third investment management services (and asset and property management services) and/or engaging in real estate development and/or launching and managing listed and unlisted real estate funds (both equity and debt) and/or participating in real estate lending directly. REITs, listed real estate companies and funds, private real estate companies and funds also typically deliver fund, asset and property management internally. Whilst most REITs and private real estate companies usually to do not offer these services to third parties, they often engage in joint ventures with investors who wish to access their skill set and asset base.

Table 2 sets out the main real estate investment organisations and outlines the way that real estate investment fits into their business models. Each of these clients/investment managers has their own unique investment objectives, constraints, corporate culture, capacity and competency, comparative and competitive advantages and end-customer. Whatever the scale, scope and model of their business and their culture, core competencies and capabilities etc., all have a common aspiration to deliver high quality operational solutions for their assets under management. The result of this diversity of investors and investment managers is a variety of operational and business models across the real estate investment management sector. Each real estate manager needs to decide which real estate operational management functions to deliver in-house and which functions to outsource based on various aspects of their business model.

\section{Real Estate Operational Management Models}

In practice, most real estate operational management models fall in between the two extremes of fully insourced and fully outsourced operational functions. In essence, nearly all real estate investment managers take some variation of a "mix and match" approach, performing some real estate operational management functions internally while engaging third party providers to execute others. As a result, there is no simple categorisation of third party providers and no single optimal model for the role of third party providers in real estate operational management and, more specifically, in property management. All investment managers have at least some degree of reliance on third party providers for some real estate operational management functions.

There are numerous permutations for procuring the broad range of real estate operational management services required. The main three broad categories are a primarily vertically integrated model, a partially vertically disintegrated model and a primarily vertically disintegrated model. The latter involves the delivery of the vast majority of operational management tasks and functions by third party providers. Typically, the investing organisations will retain ownership of the assets appointing third party investment managers using non-discretionary mandates in segregated accounts. Normally, the 
third party investment manager will also deliver asset management as well as fund management services. As discussed in detail below, third party investment managers will often tend to 'subcontract' property and facilities management to another third party provider or providers.

Whilst there will be a number of notable exceptions, as noted above it is typically sovereign wealth funds, endowment funds, small pension funds, charitable foundations and family offices that adopt this operational model. It can often be in conjunction with indirect real estate investment through various types of pooled funds where ownership as well as control of the real estate assets remains with the fund management organisation. Although many of these investors will have large real estate portfolios, the assets can be spread across global real estate markets and across a number of real estate sectors. In addition to fund, asset, property and facilities management, the execution of such international real estate investment strategies involves significant fixed costs in setting up and running a local operational platform and/or close relationships with local suppliers of a range of support services including brokerage, research, legal, accounting and tax advice inter alia.

\section{Operational Management Models}

A primarily vertically integrated or insourced model involves the delivery of most operational management tasks by the investing organisation itself. As noted above, until the last two or three decades this was probably the most common operational management model. However, over the same timeframe, like most of business sectors, there has been a structural trends towards outsourcing activities considered non-core. However, it is notable that different investing organisations managing similar types of real estate assets have taken very different views about whether essential business processes such as fund, asset and property management are core.

A partially vertically disintegrated model involves the delivery of some operational management tasks by third party providers. There are numerous options in terms of how the different tasks are procured and delivered. A common approach is to insource activities perceived to be high margin, high added value and complex analytical business processes such as asset and fund management where a competitive advantage is perceived. Business processes perceived to be low margin and low value add where there can be a large number of alternative service providers or a single third party provider for each role and task will tend to be outsourced. In particular, property and facilities management have increasingly then been perceived to be fairly commoditised activities. For both insourced and outsourced operating models, there are the numerous possibilities in terms of structuring how real estate portfolios and personnel can be grouped - by real estate sector, geographically, by fund or client. 
Before looking at the UK's commercial real estate sector specifically, it's worth re-iterating that the decision to insource or outsource an operational function is not binary. Investors may choose to manage part of the portfolio internally and to outsource asset and /or property management for specialist assets or for assets that are considered too geographically remote to manage from a main office. For instance, for a segregated fund (where a pension fund has outsourced the vast majority of operational management functions to an institutional investment manager), the institutional investment manager may choose to retain fund and most asset management functions in-house. It may outsource property management functions to a range of separate suppliers (e.g. Supplier A for shopping centres, Supplier B for residential, Supplier C for office and industrial etc.). 'Alternative' asset classes e.g. student accommodation, asset and property management functions may be outsourced to a single supplier. In turn, a whole range of other third party providers may be used for specialist services such as leasing, valuation, real estate taxation, etc. which tend to be outside the normal scope of property and asset management. Hence, the potential for relatively hybridised in-house and third party supplier networks is also significant.

\section{The UK Market Context}

Topping JLL's Global Real Estate Transparency Index in 2018, the UK has a highly mature real estate market. With a large private pensions sector and a high preponderance of leasing rather than owning among businesses, there has been a long tradition of professional real estate services firms. The service providers operate under a professional self-regulating model dominated by the RICS. Currently with over 100,000 members globally, the RICS received its royal charter in 1881. The RICS produce numerous professional statements, codes, practice notes, information papers etc. that form a core component of the professional self-regulation of a wide range of real estate services. They tend to focus on common governance themes such as clarity and fairness in terms of engagement, maintenance of conflicts of interest databases and reference to complaints-handling procedures and redress schemes. In 2016, the RICS released the Real Estate Management Professional Statement to advise members on aspects of their work in this area (RICS, 2016). It recommends procedures for specific professional tasks intended to represent best practice. Its Information Paper in 2016 provided detailed information about the roles and functions of property, asset and fund managers (RICS, 2016).

For the UK, the IPF (2017) estimated that the commercial real estate investment universe was worth approximately $£ 486$ billion in 2016 representing around 400 million square feet of space. MSCI (2018) estimate that, in 2017, it was the third largest institutional real estate investment market accounting for approximately $10 \%$ of the global universe. To non-UK readers, it may be striking that there is relatively little institutional investment in the residential sector with student accommodation and the Private Rented Sector accounting for an additional $£ 37$ billion of assets. However, institutional involvement in 
such 'alternative' sectors has been growing rapidly. Although the concepts of domestic and nondomestic are becoming increasingly difficult to disentangle, it was estimated that nearly $30 \%$ of the total was owned by non-domestic investors. The weight of London is notable. It accounted for $£ 250$ billion of the $£ 486$ billion. Whilst there is no standard nomenclature, the largest groups of investors were collective investment funds ( $£ 79$ billion), REITs and listed companies ( $£ 74$ billion) and private companies ( $£ 60$ billion).

A notable feature of the regulatory regime regarding services charges in the UK is that that much of the cost of managing multi-let assets is payable by the tenant through the service charge. Indeed, owners are permitted to generate a profit from the delivery of services. The RICS Professional Statement Service Charges in Commercial Property states

"The management fees charged shall comprise only the reasonable costs and overheads borne in the process of operating and managing the services. These would also reflect the actual work necessary to fulfil the principles of this professional statement. It is recognised that whoever is providing the service is entitled to cover their costs and overheads, including a reasonable profit element." (RICS, 2018, 14)

This also includes irregular charges for administering non-routine events such as permissions to alter the premises, sublet etc. Where third party providers are involved, additional services that are not specified in the property management agreement will involve additional payments subject to negotiation. Typically, owners pay a separate fixed fee for rent collection and other management services. This may be on a per lease or per building basis.

As one of the most globalised and financialised commercial real estate markets, it could be argued that it is inappropriate to refer to the UK context. In a European setting, London has the largest geographical cluster of human capital in real estate support services. It is a major destination of, source of and 'entrepôt' for cross-border real estate capital flows. The main offices of the leading full service real estate services providers e.g. CBRE, Cushman and Wakefield and JLL are located there. In addition, the major global and European real estate information and benchmarking services are in London e.g. MSCI, PMA, CoStar and RCA. Nearly all major global investment managers have offices in London which, in turn, is a leading centre of corporate real estate and FM knowledge. London is also a cluster of large groups of advanced producer service providers e.g. accountancy, legal, banking etc.: many of which have large sections that specialise in real estate.

The wider commercial real estate market has been characterised by "increasing options for investing in real estate internationally, with a series of more robust and better-governed investment platforms 
covering most of the world's real estate markets." (Aussant et al, 2014, 3), Perhaps not surprisingly, in a study of foreign investment in commercial real estate in 28 major European cities, McAllister and Nanda (2016) found that London alone accounted for more than 50\% of transactions (by value) involving non-domestic investors. The execution of such international real estate investment strategies often involves significant fixed costs requiring a local operational platform and/or close relationships with local suppliers of a range of support services including brokerage, research, asset and property management, legal, accounting and tax advice inter alia. There are also significant scale economies associated with many search, holding and operating costs. As a result, it has become increasingly difficult to categorise many real estate investment organisations by nationality or business focus.

There is very little literature on the structure of the contemporary real estate investment management sector. Vistra (2018), a major provider of fund administration services, provide a broad overview of the evolution in the real estate investment management sector. They argue that the sector has been increasingly subject to pressure for increased operational efficiency and cost-effectiveness. Vistra discuss a number of fairly familiar trends including the consolidation of operations with fewer outsourcing partners, an increased propensity to use dedicated procurement functions to appoint and oversee third party service providers and a growth in the range of services outsourced by fund managers. Reinforcing the discussion above, they also point to broader structural changes such as increased variety of real estate investment products, a growing investor appetite for alternative asset types and new geographical markets and major changes within the core retail, office and industrial sectors.

Before assessing the third party property management sector in the UK, it is worth noting that there is little to distinguish the UK fund and asset management sector from the broader global market. Perhaps, the most pertinent point to reiterate is that most categories of investing institution have a significance presence in the UK. Parker et al. (2018) provide an overview of the structure of the real estate fund management sector focusing on the distinction between whether asset ownership is retained by the client or handed over to the fund manager with the client investing in a real estate fund. They identify different motivations and reward structures with listed vehicles focussed on shareholder value and private funds focussed on fee income. They point out that some real estate operational management activities lend themselves to being outsourced and briefly discuss a number of familiar considerations in the outsourcing decision around cost, control, communication, expertise, flexibility and conflicts of interest. Their conclusion is that

"[A]s individual situations differ, there is no simple guide to the decision whether to use outsourced service providers or in-house staff. Often, some combination of the two models is adopted by fund managers... While the adoption of a wholly in-house business model by a fund manager is now effectively non-existent" (Parker et al., 2018, 125) 


\section{The Third Party Property Management Sector in the UK}

In terms of the supply-side for property management services, in the UK there are two main categories of third party solutions. A small number of providers (e.g. Workman, MJ Mapp) have a fairly narrow set of offerings specialising in property management on a stand-alone basis. Much more well-known, other global full-service providers (Cushman \& Wakefield, Savills, CBRE, JLL) offer a much more comprehensive range of services to support a variety of real estate operational management processes. This range of services has expanded significantly as the demand for improved real estate operational management capability from their clients (real estate investment managers) has grown. Possibly reflecting increased vertical integration of the supply chain, CBRE's acquisitions of FM service providers such as Global Workspace Solutions and FacilitySource and M\&E specialists such as Norland are symptomatic of the changing landscape in outsourced real estate operational management. Comparable acquisitions by Cushman and Wakefield of Quality Solutions and by JLL of Integral are also indicative this shift.

There is very little documented knowledge about the nature of the property management sector in the UK. A notable exception is a study by RealService for the British Council for Offices in 2015 on occupier satisfaction. Their research identified relatively high negative perceptions of the property management sector by occupiers. A number of findings stood out. Compared to many other business services, occupiers perceived that there had been little innovation in property management. In terms of their overall experience of occupying buildings, property management was identified by occupiers as the area that required most improvement. Despite the consolidation in the wider real estate services sector, the property management industry was perceived to be heavily fragmented with many suppliers, making it difficult to achieve economies of scale and to achieve thought leadership through innovation. Other problems identified were a lack of industry standard systems and business processes. The result is that property management processes were perceived to be inefficient and labour intensive.

In the same study, in summaries of comments from focus groups, property managers were arguing that the increasing expectations on health and safety, environmental issues, client reporting and occupier engagement placed on them by clients and occupiers had never been greater. Overall, the findings were consistent with a perception that the sector has increasingly been commoditised and has evolved into a relatively low skill, low margin and low status function in the real estate services supply chain. There is anecdotal evidence to suggest that these typical perceptions among occupiers are also held by the investors. More recently, prominent real estate industry figures have questioned the current strategic and operational resilience of the property management supply network used by many investment managerss. For instance, in 2018 Bill Hughes, Head of Real Assets at Legal and General Investment Managers (one of the top five in terms of real estate assets under management in the UK), argued that 


\begin{abstract}
...the existing presumption of outsourced property management is no longer fit for purpose and needs to change... The decision to outsource property management is commonly propelled by the property owner requirements to reduce costs and save time. In reality it's left with a managing agent in the middle who, very often, does not have the motivation or skillset to look after the needs of the occupier or run a building efficiently...With a growing body of legislation covering energy consumption, waste and its reduction, there is an increasing burden on the managing agents to provide services that they are not equipped to offer. The Property Manager function now needs to actively participate in customer service, facilities maintenance and engineering, sustainability and CSR strategic thinking - not to mention rent collection and day-to-day maintenance. The emergence of these areas for property owners shines a spotlight on the existing industry skills gap.
\end{abstract}

Sponsored by CBRE (a major supplier of third party property management services), Fick (2015) analysis aimed to challenge the "orthodoxy" of in-house property management by US REITs. The broad argument is that hardly any REITs can achieve the economies of scale of major third prarty providers and that the professed advantges o of in-house management are largely unproiven. The main arguments for insourced property management models such as branding, enhanced control, staff cohesion and co-ordination, entrepreneurship, property management as a profit centre and scale economies are challenged. In turn, a number of benefits of outsourced property management such as economies of scale in purchasing, contracting and human resource efficiencies that only large scale external managers can generate are proposed. It is argued that quality assurance will be more robust in third party models which are more likely to have more standardised systems and metrics. The ability to flexibly adjust the portfolio in response to strategic shifts in portfolio composition is then proposed.

Using a qualitative, interview-based research method, Falkenbach et al. (2017) investigated the costs and benefits of outsourcing property management for 15 institutional investors in UK, Netherlands and Finland. They concluded that it was the commonalities between models and investors rather than the divergences that dominated. They also found that the perceived costs and benefits of third party property management solutions corresponded with many of the factors identified in the broader outsourcing literature and in Fick (2015). Key advantages recognised were the ability to transfer fixed into variable costs and, consequently, to externalise the operational risks involved in portfolio rebalancing. In addition, third party providers can benefit from economies of scale in aggregating the portfolios of a range of clients. It was also recognised that third party solutions provided opportunities for investors to gain access to expertise in specialist areas (e.g. sustainability, data management, health and safety). Arms-length relationships with third party providers were believed to enable more robust quality assurance and performance monitoring. However, it is notable cost savings did not emerge as a key issue. Indeed, a frequent observation focused on the need to balance quality of service with pressures to generate operational efficiencies.

Focussing on outsourced property management in the US residential real estate sector, Read et al. (2016) investigate two main research questions using qualitative, interview based methods. The first question focussed on the extent to which property managers view fee structures, reporting requirements 
and incongruent managerial philosophies as significant sources of conflict when working with institutional asset managers. The second considered the extent to which large property management firms are proactively taking steps to mitigate such conflicts where and when they are perceived to exist. It was found that best-in-class apartment management companies were combating fee compression and commodification in their industry by promoting the value-add nature of their services. Third party property managers were also found to be increasingly working with their clients to design nontraditional fee structures that appropriately incentivise all members of the management team to work toward defined strategic objectives. In addition, increased reporting requirements driven by institutionalization of the sector were being facilitated by digital technologies.

\section{Real estate operational management models in practice}

\section{Insourced Approaches}

In the UK, a significant number of real estate investors tend to use primarily insourced operational management models. A mainly insourced model is found for large traditional estates, Large contiguous tracts of prime central London real estate are owned by, what are often termed, traditional, landed or settled estates such as the Crown Estate, Cadogan Estate, Howard de Walden Estate, Grosvenor and Portman Estate that, despite their prima facie similarity, adopt different operating models. As one of the largest in scale, Grosvenor's property management model also involves in-house delivery augmented by the bulk purchase of specialist services from external contractors and, for particular lease events, flexibility for asset managers to instruct third party providers or deliver in-house on an ad hoc basis. Third party delivery of specialist services is typically organised through a small number of mandated suppliers for each externally sourced specialist service. In addition, there is also an evolving trade-off between commercialism and stewardship. Until recently, Grosvenor have reportedly run their property management services at a loss. This seems to reflect their proto-patrician origins and desire to be perceived as a fair landlord.

A key determinant of this insourced operating model seems to be the geographical concentration of the portfolio. In particular, similar to a shopping centre, there is a perceived need to manage and control highly spatially concentrated, neighbourhood-scale, clusters of assets often in fairly small lots. This creates both operational efficiencies and inefficiencies. The spatial concentration provides economies of scale due to agglomeration-type economies whilst the small lot sizes produces higher operational costs per unit of space. For assets in the same neighbourhoods that are owned by third parties, Grosvenor will also offer property management services. However, this is a fairly minor part of their assets under management. 
At the time of writing Cadogan Estates have a slightly larger estate than Grosvenor with typically larger lot sizes. It is worth approximately $£ 6$ billion at time of writing. Whilst it is also spatially concentrated, the estate is less amalgamated in that the estate tends to own blocks of assets along major thoroughfares such as King's Road rather than whole neighbourhoods. They operate what they describe as a hybrid model for property management. For the non-income producing properties (mainly long leasehold residential assets) for which the estate is responsible for property management, this function is outsourced to 10-15 third party providers. However, the property and asset management for incomeproducing assets (both residential and commercial) is delivered in-house. It is perceived that in-house delivery is optimal because of the need to build customer relationships, control and ensure service quality. Whilst dozens of specialist contractors will deliver many of the services, with most customers within a ten minute walk of the owner's offices, it is felt to be important to maintain a 'direct line' with the customer to maximise income. Similarly, internal asset managers will be responsible for capital and leasing transactions with the flexibility for asset managers to use retained or non-retained third party providers or deliver in-house on an ad hoc basis

Also largely insourced, another interesting apparent contrast in operating models is between Landsec and British Land. Recently overtaken by SEGRO in terms of market capitalisation, historically both companies have been the largest listed real estate investment and development companies in the UK with an asset base spread across sectors and, almost exclusively UK, geographies. Whilst both delivered core property and asset management functions in-house, their operating models diverged in the last two decades. Landsec's operating model has remained largely stable whilst its portfolio has become more concentrated and specialised in terms of the location and size of its asset base. British Land has had a similar rationalisation of its asset base. However, following its development of Broadgate in central London, in 1986 British Land set up a subsidiary (Broadgate Estates) to deliver property management functions. This subsidiary increased in size as it took on property management mandates from owners in the vicinity of Broadgate. As the subsidiary expanded, British Land decided that they would procure all their property management through Broadgate Estates. The result was that Broadgate Estates became responsible for the property management of their assets as well as those of third parties. Their argument for outsourcing to a single wholly owned subsidiary was that it would enable them to rapidly capture and transfer best practice learnings across their portfolio.

By 2016, Broadgate Estates had grown into a team of 500 people managing 83 assets across the UK, approximately half of which were owned by British Land. The third-party portfolio comprised contracts to manage 28 locations in London and Liverpool for 14 clients. In 2018, Broadgate Estates was sold by British Land to a full-service global real estate advisory firm - Savills ${ }^{1}$. However, only the third party

\footnotetext{
${ }^{1}$ In 2016, Savills also acquired GBR Phoenix Beard - a leading specialist property management services firm
} 
business was sold. The property management of British Land's portfolio was effectively back-sourced with the company now delivering property management internally. The rationale seems to be that in a progressively competitive market (especially for shopping centres), it has become increasingly important for British Land to build relationships with and to improve their organisational knowledge of their customers. With increasing priority put on ensuring that existing tenants are satisfied and potential tenants are attracted, there seems to be an embryonic but growing challenge to the outsourcing model.

It is difficult to see any significant exceptions to the rule that UK REITs insource the operational management of their portfolios. Both sector specialists such as SEGRO, INTU and Hammerson and location specialists such as Great Portland Estate and Derwent London deliver asset and property management in-house. Reflecting the conventional arguments for in-house delivery, Great Portland Estates state in their Annual Report that

"We consider that a close relationship with our occupiers is vital to our success. As a result, we manage all aspects of our property portfolio in-house, enabling us to continually refine our understanding of what occupiers want and how we can meet their needs." (Great Portland Estates, 2018, 42)

\section{Hybrid Approaches}

In the UK, there is an almost universal operating model for the third party investment management sector for real estate operational management. Without exception, this involves insourcing the vast majority of fund and asset management functions and outsourcing the vast majority of property and facilities management functions to third party providers. Comprising mainly of insurance companies, fund houses, investment managers, specialist real estate investment managers, and investment banks, it is difficult to identify any exceptions to this model. Typically managing shifting, multi-sector, geographically diversified real estate portfolios, the business focus is on the analytical, complex and higher margin business processes associated with asset and fund management. Even where specialist real estate funds are launched and managed, the emphasis is on maintaining the culture of a high status, knowledge intensive and well-remunerated core workforce. Low margin and largely commoditised functions such as property management and fund administration are then outsourced. Property management, facilities management and other specialist real estate operational management services are effectively subcontracted to external suppliers. Kevin Bould of Royal London Asset Management succinctly sums up the purported rationale for this fairly typical operating model.

"Contract management does not always sit easily with fund managers who view this work as important but dull. It is however a vital element of every successful property fund as getting it wrong can increase workload and distract the team from our key objective of generating outperformance. RLAM has sought to outsource non-core functions where we cannot add value, allowing the team to devote resources where it really matters, adapting 
our approach dependent upon the materiality of every contract. This in turn allows fund and asset managers to concentrate their efforts to maximise the impact upon investment returns.” (Royal London Asset Management, 2015, 10)

For property management, as noted above, Falkenbach et al. (2017) argued that these investing institutions are essentially prepared to absorb the 'costs' of outsourcing such as reduced control, mediated relationships with tenants, potential information leakage, potential shirking, loss of potential income stream and other potential conflicts of interest. In return, they implicitly judge that the perceived 'benefits' of third party solutions such as operational flexibility, ability to focus on core competencies and higher margin activities, access to specialist knowledge and lower headcount outweigh the disadvantages. Whilst the potential for economies of scale and operational efficiencies from third party delivery is recognised, it is notable that cost reduction has generally not been perceived as an advantage of third party solutions. Rather the key concern seems to be the calibration between service quality and cost.

An interesting exception to the pattern of geographically concentrated portfolios insourcing property management is the Crown Estate. Although they own approximately the same amount of real estate assets in central London (by value) as Grosvenor and Cadogan Estates with little difference in spatial concentration, they have opted to outsource their property management to a full-service real estate advisory firm. In 2015, Crown Estate appointed JLL to oversee Regent Street Management Direct (RSMD) for a five year period. Essentially the terms of the contract saw JLL 'white label' their property management service under the RSMD brand responsible for property and facilities management and day-to-day relations with the occupiers on Regent Street. Crown Estate retained asset management functions in-house. However, their wider portfolio is more diverse with the central London assets accounting for approximately $55 \%$ by value. Other commercial real estate and agricultural holdings are quite widely dispersed throughout the UK. A relatively small range of third party providers of property management services are mandated for this element of the portfolio.

In terms of the procurement model for third party property management services, there is significant variation among investing institutions in terms of number of suppliers, performance metrics and the use of incentives and penalties. Whilst some investing institutions use a single supplier, 'one stop shop' approach and other have dozens of suppliers, an optimal operational model seems to be emerging. This involves a relatively small number of third party suppliers (4-6). This model reduces supplier risk associated with having a single provider whilst also lowering the costs associated with managing dozens of external supplier relationships. The flexibility to use whoever is identified as the best provider in a specific sector or market is retained. In addition, competitive tension is maintained by having the ability comparing pricing and performance among suppliers. Further, the quality of service is likely to be enhanced when the institution's mandate is of a sufficient scale to ensure that they remain a key client 
of the supplier. Multiple suppliers also ensures that the capacity for knowledge sharing and exchange of good practice is preserved.

\section{Outsourced Approaches}

The final broad category of real estate operational management model is to outsource responsibility for fund, asset, property and facilities management to third party providers. This is closely linked to the hybridised model outlined above. Many of the organisations that adopt hybrid models act as direct third party providers of fund and asset management to investment organisations that outsource these activities. These investment management firms are, in turn, responsible for the procurement of other real estate services from other third party providers. In the UK, the client investing organisations will retain ownership of the assets appointing third party investment managers who normally act as quasigeneral contractors. With the third party investment manager delivering asset and fund management services, they typically sub-contract property management, facilities management and other specialist real estate services to a range of third party providers. In turn, the property and facilities managers may sub-contract some specialist services to other suppliers. This is analogous to the construction sector where main contractors have a direct commercial relationship with a client are termed Tier 1 . Subcontractors and suppliers with a direct contract with the Tier 1 main contractor are termed Tier 2. Subcontractors and suppliers working for sub-contractors are termed Tier 3 and Tier 3 sub-contractors also employ suppliers and sub-contractors, so in many cases there can be a fourth or even fifth tier involved in delivery (Department for Business Innovation and Skills, 2013).

In the wider investment sector, it is possible that the relative importance of outsourcing may decline. Rozanov (2017) identified a secular shift in so-called best-in-breed sovereign wealth funds and large public pension funds towards building and expanding internal portfolio management capabilities. For instance, Oxford Properties invests in and manages real estate assets in the UK as a subsidiary of the Ontario Municipal Employees Retirement System, one of Canada's largest pension funds. In a large, local (to the author's university) business park in Reading, asset management functions were delivered by Oxford Properties by on-site staff. However, property management functions were outsourced to a specialist in property management (themselves taken over in 2018 by a full service real estate advisory firm - see below). Adopting a white labelling model, the property management service, however, was branded with the business park rather than with the service provider.

\section{Conclusion}

Across the real estate investment sector, many markets have continued to mature and become more sophisticated. The real estate investment management sector and associated third party providers of 
real estate services to deliver real estate operational management functions have expanded their operations. The globalisation of commercial real estate markets and the investment management sector has significantly changed the commercial real estate investment landscape. Over the last two decades, a secular shift towards outsourcing more and more elements of real estate operational management has been a key factor in the growth of third party service providers. As the composition and business models of investment organisations and service providers have evolved, changing regulatory, user and investor requirements, increasingly complex buildings, the emergence of 'alternative' real estate asset classes and structural change in conventional real estate asset classes are driving continuing change in the processes involved in the operational management of commercial real estate portfolios.

Whilst categorisation of investor type can be challenging, a range of operating models are used in the operational management of real estate portfolios. With the exceptions of specialist real estate investment managers, specialists in real estate tend to view most operational management functions as core competencies and critical operational capabilities. Their operating model is highly vertically integrated. In contrast, major (multi) asset owners such as national pension and sovereign wealth funds tend to have a vertically disintegrated real estate operational model with fund, asset, property and facilities management often outsourced to external investment managers. This can be done indirectly by investing in private and public pooled vehicles and transferring both asset ownership and management to third parties. Alternatively, it can be executed directly through separate account mandates where ownership is retained and operational management is outsourced. Capital aggregators or investing institutions such as fund houses, investment banks, insurance companies and specialist real estate investment advisors offer both options to investors. Over the last two decades, these capital aggregators seem to have converged upon a single operating model for real estate operational management with high margin, analytical tasks such as fund and asset management functions being insourced and low margin, routine functions such as property and facilities management being outsourced. The degree of convergence in terms of operating model within the various investor categories would suggest that the operating models are optimal for their specific business models.

In the UK specifically, it is apparent that real estate investment organisations with highly geographically concentrated portfolios tend to insource. The customer is close and, similar to shopping centres, they wish to curate and control clusters of assets. Investment organisations who regard themselves as real estate specialists also tend to insource the core functions of property, asset and fund management. All the major REITs, some of whom are sector specialists, tend to insource. The clear exception here the large specialist real estate investment managers such as AEW, CBRE Global Investors and Lasalle Investment Management. Given that CBRE Global Investors manage real estate and infrastrucutre investment worth $\$ 106$ billion for nearly 600 institutional clients from 32 offices in over 20 countries, it is unlikely to be optimal to create a property management capability in each market. Like the specialist 
real estate investment managers, multi-asset investment managers invariably tend to outsource property management and deliver asset and fund management in-house. Although the effectiveness of this model is starting to be questioned, it is difficult to find any exceptions to this pattern. In the UK, in 2011, the last hold-out $(M \& G)$ 'lifted and dropped' their property management team into CBRE.

Looking ahead tentatively, there is embryonic evidence of some potentially significant shifts. Whilst the large full-service firms have been increasing their range of services in response to investor demands, there seems to be significant dissatisfaction with third party property management. Perhaps peak outsourcing has been reached. Large asset owners are increasing insourcing fund management reducing separate account mandates. Structural changes in the real estate market, particularly in shopping centres and office markets, may mean that pro-active, customer-focused and entrepreneurial management will become an increasingly critical capability that is less likely to be outsourced. The emergence of white labelling models may begin to blur the boundaries between in-house and outsourced operating models. Invariably, digitisation will continue to increase the supply of and demand for the provision of data, information and, consequently, actionable intelligence. 


\section{References}

Aussant. J, P. Hobbs, L. Yang, and P. Shepard. (2014). The Erosion of Real Estate Home Country Bias, MSCI Research Report. 2014, 1-15.

Baum, A.E. and Hartzell, D (2012). Global property investment: strategies, structures, decisions. .John Wiley \& Sons.

BCO (2015) Building Performance - Rethinking the relationship between owners, managers and occupiers

Department for Business Innovation and Skills. (2013). Supply Chain Analysis into the Construction Industry: A Report for the Construction Industrial Strategy. BIS Research Report, Number 145.

Falkenbach, H., Jylha, T., Levy, D., McAllister P. and Remøy, H. (2017). Outsourcing Property Management? An Evaluation of the Rationales and Motivations. SSRN Electronic Journal. 10.2139/ssrn.3339252.

Fick, D. (2015). Challenging REIT Property Management Orthodoxy. Retrieved from https://www.cpexecutive.com/media/pdfs/REIT-Whitepaper.pdf

Great Portland Estates (2018). Unlocking Potential: Annual Report 2018. IPF (2018). The Size and Structure of the UK Property Market Year End Update-2017 Gallimore, P., Hughes, C. and McAllister, P. (2006). Property stock selection: organization, incentives and information. Report for Investment Property Forum.

Geltner, D. (2003). IRR-based property-level performance attribution. The Journal of Portfolio Management, 29, 5, 138-151.

McAllister, P. and Nanda, A, (2016). Do Foreign Investors Compress Real Estate Capitalisation Rates? Journal of Real Estate Research, 38, 569-594.

Parker, D., Moss, A., McNamara, P. and Goodchild, R. (2019) Fund Management, in (eds) MacGregor, B., Schulz, R. and Green, R., Routledge Companion to real Estate Investment. Read, D.C., Hopkins, E., \& Goss, R.C. (2016). Working effectively with asset managers and institutional groups. Property Management, 34, 280-296. doi: 10.1108/PM-07-2015-0031 RICS (2016). Real Estate Management, RICS Professional Statement RICS (2016) Real Estate Fund, Asset and Property Management: Investment Services, Professional RICS Professional Guidance RICS (2018). Service Charges in Commercial Property, RICS Professional Statement. Royal London Asset Management. (2015) Real Insights: Quarterly Property Report, Issue Two. 
Rozanov, A., (2017). Public Sector Investment Funds: How the Best-in-Breed Evolved. Working Paper Series, Columbia Business School.

Teuben, B. and Bothra, H. (2018) Real Estate Market Size 2017, MSCI Research Report. Vistra. (2018). Real Estate Fund Operations: An Asset Manager and Sovereign Wealth Fund Perspective 


\section{Table 1}

\section{The Operational Management of Real Estate Investment Portfolios: A Task Audit}

Main property management functions

- Rent collection and credit control

- Service charge budgeting and collection

- Guarantees and deposits

- Insurance

- Procurement of service providers (maintaining, M\&E servicing, repairing, cleaning, securing, landscaping, concierge, waste management, energy management and other utilities]

- Licences (alter, surrender, assign, sublet)

- Tenant liakson and communication

- Inspection, monitoring and enforcement

- Client liaison and reporting

- Dilapidations

Facilities management functions

- Soft FM services

- Hard FM services
Main asset management functions

Transaction execution

Leasing strategy

Asset marketing strategy

Reporting to fund manager

Liaison with and monitoring of PM

- Assetplanning

Budget control

Procurement of specialist services

- Project management of capex

Specialist real estate functions

Investment brokerage

Leasing brokerage

Rent reviews negotiations

- Lease renewals negotiations

Independent valuation

Health and safety assessments

- Sustainability

- Fire safety compliance

Local real estate taxes
Main fund management functions

- Investment decisions - asset allocation and stock selection

- Liaison with and monitoring of AM

- Operational and investment performance measurement and management

- Investor relations

Fund valuation

- Financing

- Structuring

- Corporate governance

- Compliance and audit

- Regulatory reporting

Supporting legal services

Accounting and treasury services

Data and document management

Research 
Table 2

Real Estate Investors: Business and Operating Models

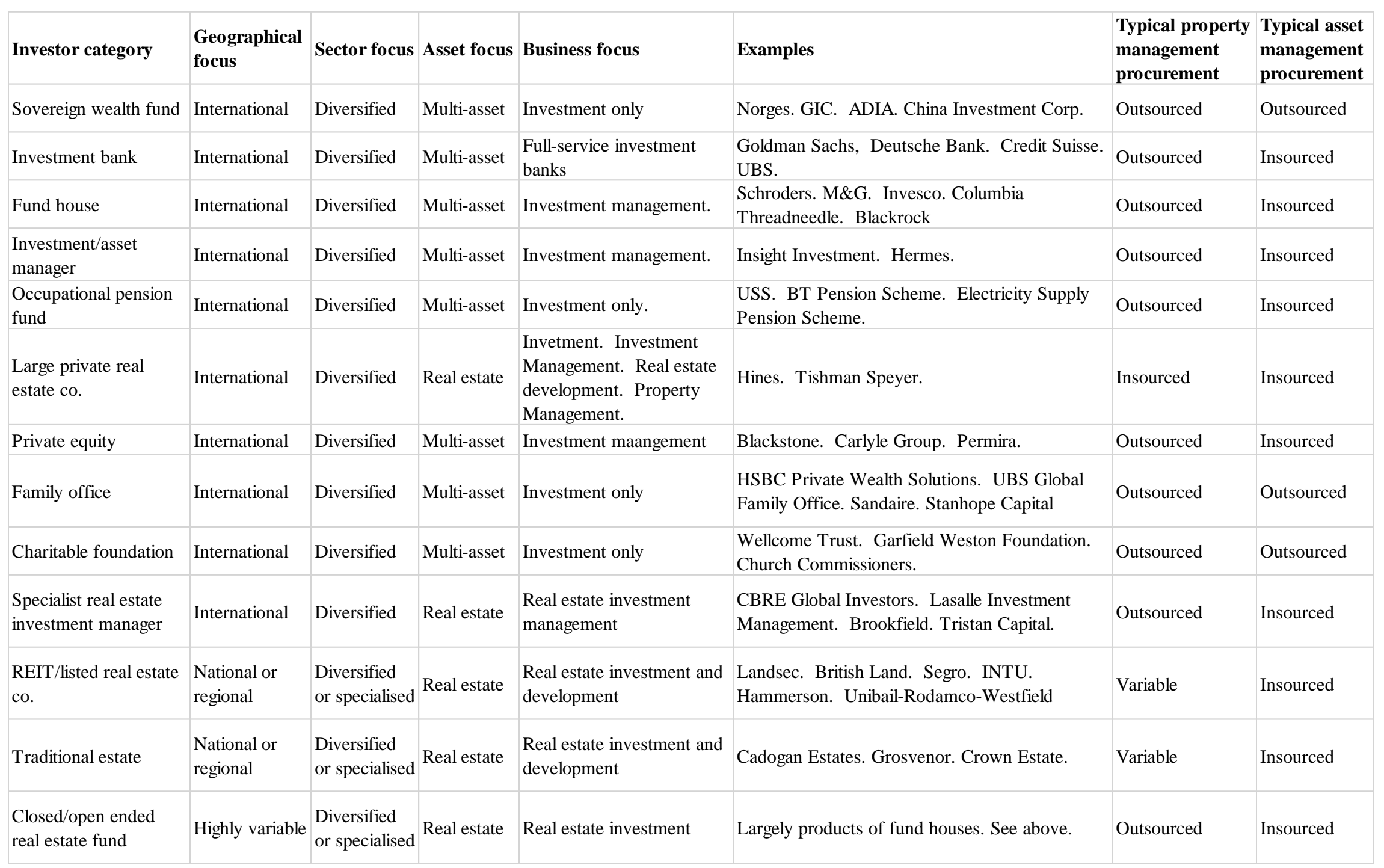


Figure 1

Property-facilities management and investment performance

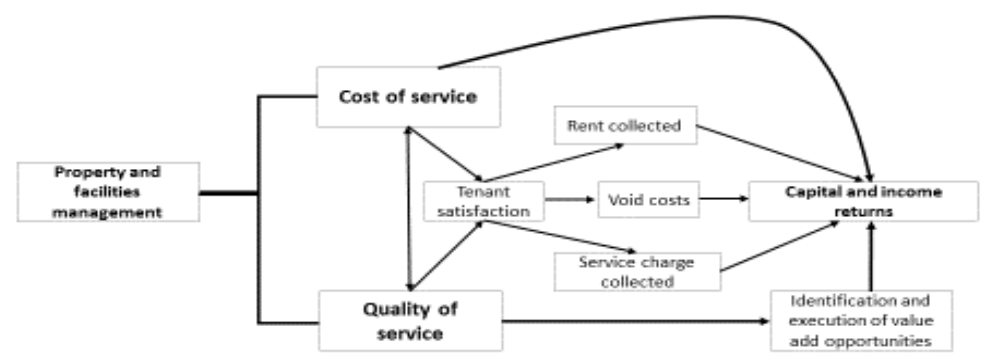

Figure 2

Asset management and investment performance

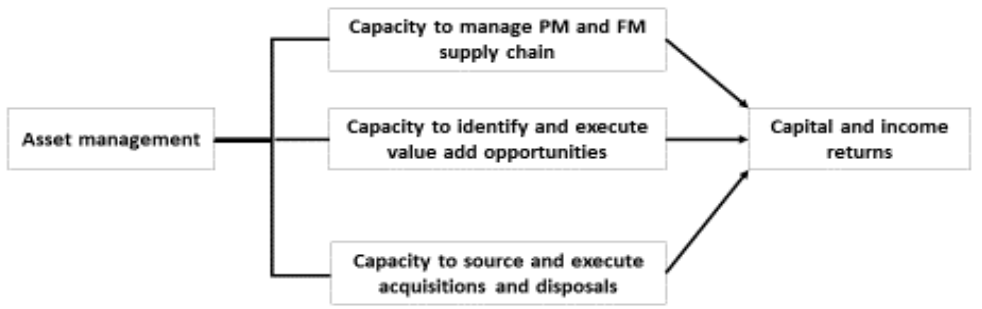

Figure 3

Fund management and investment performance

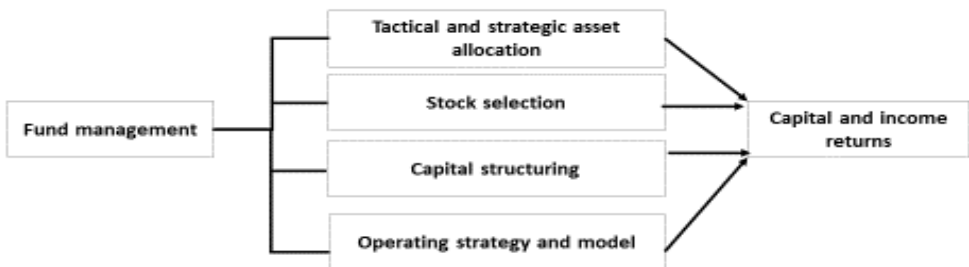

